\title{
PENGARUH STRATEGI PEMBELAJARAN INKUIRI DAN MOTIVASI BERPRESTASI TERHADAP HASIL BELAJAR PELESTARIAN LINGKUNGAN HIDUP
}

\author{
Jonson Hulman Siburian, Samsidar Tanjung, Abdul Hasan Saragih \\ Sekolah Menengah Atas Negeri 1 Lintong Nihuta, Kabupaten Humbang Hasundutan \\ Jonson_hulman@gmail.com
}

\begin{abstract}
Abstrak: Penelitian ini bertujuan untuk mengetahui: (1) hasil belajar pelestarian lingkungan hidup antara siswa yang diajar dengan menggunakan strategi pembelajaran inkuiri lebih lebih unggul daripada hasil belajar mengolah pelestarian lingkungan hidup yang diajar dengan menggunakan strategi ekspositori; (2) Mengetahui keunggulan hasil belajar pelestarian lingkunganhidup antara siswa yang memiliki motivasi berprestasi tinggi lebih unggul daripada hasil belajar pelestarian lingkungan hidup siswa yang memiliki motivasi berprestasi rendah; dan (3) Mengetahui interaksi antara strategi pembelajaran dan motivasi berprestasi siswa dalam memberikan pengaruh terhadap hasil belajar pelestarian lingkungan hidup. Metode yang digunakan adalah metode eksperimental gunanya untuk membandingkan mana yang lebih baik antara strategi pembelajaran inkuiri dan strategi pembelajaran ekspositori. Kesimpulan dari penelitian ini adalah: (1). Hasil belajar pelestarian lingkungan hidup yang diajar dengan strategi inkuiri lebih tinggi dari pada hasil belajar pelestarian lingkungan hidup yang diajar dengan strategi ekspositori; (2) Hasil belajar pelestarian lingkungan hidup yang memiliki motivasi berprestasi tinggi lebih tinggi dari hasil belajar pelestarian lingkungan hidup yang memiliki motivasi berprestasi rendah; dan (3). Terdapat interaksi antara strategi mengajar dan motivasi berprestasi terhadap hasil belajar pelestarian lingkungan hidup.
\end{abstract}

Kata Kunci: strategi pembelajaran inkuiri, motivasi berprestasi, pelestarian lingkunagn hidup

Abstract: This study aims to find out: (1) learning outcomes of environmental preservation among students taught using inquiry learning strategies are superior to the results of learning to process environmental preservation taught by using expository strategies; (2) Knowing the superiority of learning outcomes in environmental preservation among students who have high achievement motivation are superior to learning outcomes of environmental preservation of students who have low achievement motivation; and (3) Knowing the interaction between learning strategies and student achievement motivation in influencing learning outcomes for environmental preservation. The method used is an experimental method to compare which is better between inquiry learning strategies and expository learning strategies. The conclusions of this study are: (1). The results of learning to conserve the environment taught by inquiry strategies are higher than the results of learning to conserve the environment taught by expository strategies; (2) Learning outcomes of environmental conservation that have high achievement motivation are higher than learning outcomes of environmental conservation that have low achievement motivation; and (3). There is an interaction between teaching strategies and achievement motivation towards learning outcomes of environmental preservation.

Keywords: inquiry learning strategy, achievement motivation, environmental preservation

\section{PENDAHULUAN}

Sekolah sebagai suatu institusi atau lembaga pendidikan yang merupakan sarana melaksanakan tujuan pendidikan dengan melaksanakan proses pembelajaran. Sekolah dipandang sebagai suatu organisasi yang membutuhkan pengelolaan oleh orang-orang yang profesional (Sagala, 2007:71). Kegiatan inti organisasi sekolah mengelola SDM yang diharapkan menghasilkan lulusan yang berkualitas, sesuai dengan kebutuhan masyarakat. Lulusan sekolah diharapkan dapat memberikan kontribusi yang signifikan terhadap pembangunan bangsa. Wahjosumidjo (2008:136) mengemukakan sekolah adalah sebagai sebuah organisasi tempat untuk mengajar dan belajar serta tempat untuk menerima dan member pembelajaran, terdapat 
orang atau sekelompok orang sebagai sumber daya manusia dalam satuan kerja yang melakukan hubungan untuk mencapai tujuan. Dengan demikian dapat dikatakan bahwa sekolah sebagai institusi pengelola pelayanan pendidikan diharapkan dapat memfungsikan seluruh sumber daya yang ada secara efektif dalam mencapai tujuan dan efisien dalam menggunakan sumber daya tersebut, salah satunya adalah guru.

Peranan guru dalam pembelajaran geografi khususnya pada materi pendidikan lingkungan hidup sangatlah berperan dalam meningkatkan hasil belajar siswa. Ketika proses pembalajaran guru harus dapat menciptakan suasana yang menarik dan menyenangkan. Salah satu usaha yang dilakukan oleh guru adalah ketepatan dalam memilih strategi pembelajaran. Strategi yang tepat dalam proses pembalajaran akan lebih mempercepat pencapaian tujuan yang akan dicapai. Hal ini sesuai apa yang dikemukakan Kemp dalam (Sanjaya 2007:124) bahwa strategi pembelajaran adalah suatu kegiatan pembelajaran yang harus dikerjakan guru dan siswa agar tujuan pembelajaran dapat dicapai secara efektif dan efisien.

Ada beberapa strategi yang digunakan dalam melaksanakan pembelajaran Menurut Sabri (2010:10) ada empat strategi pembelajaran, yaitu: (1) Strategi Ekspositori atau model Informasi; (2) Strategi inkuiry; (3) Strategi interasksi sosial; dan (4) Strategi tingkah laku. Selanjutnya Knowles dalam Sudjana (2001:15) trategi digolongkan kedalam 7 jenis, yaitu (1) penyajian yang mencakup: ceramah, siaran televise dan videotape, film dan slide, debat, dialog, Tanya jawab, simpsium, panel wawancara kelmpok, demonstrasi, drama, dan pementasan; (2) pembinaan partisipasi mencakup: forum, kelompok pendengar, panel berangkai dan bermain peran; (3) diskusi; (4) simulasi mencakup: pemecahan masalah dan studi kasus; (5) latihan kelompok; (6) latihan tanpa bicara ; dan (7) latihan keterampilan.

Guru masih jarang mengajar memakai strategi ekspositori dan strategi inkuiri. Menurut Sabri (2010:10) strategi ekpositori bertolak dari pandangan, bahwa tingkah laku kelas dan penyebaran pengetahuan dikontrol dan ditentukan oleh guru. Sedangkan strategi inkuiri menganggap bahwa siswa sebagai subyek dan obyek dalam belajar, mempunyai kemampuan dasar untuk berkembang secara optimal sesuai dengan kemampuan yang dimilikinya.

Di sisi lain rendahnya kualitas hasil siswa selain dipengaruhi oleh faktor ekternal, tetapi juga dipengaruhi oleh faktor internal yaitu dari dalam diri siswa itu sendiri. Faktor internal yang mempengaruhi keterampilan belajar siswa adalah motivasi berprestasi siswa itu.

Menurut Robbins (2006:213) mendefenisikan motivasi sebagai proses yang ikut menentukan intensitas, arah, dan ketekunan individu dalam usaha mencapai sasaran. Sedangkan Sardiman (2004:2) Motivasi adalah sebagai kekuatan, dorongan, kebutuhan, semangat, tekanan, atau mekanisme psikologi yang mendorong seseorang atau sekelompok orang untuk mencapai prestasi tertentu sesuai dengan apa yang dikehendaki. Dapat dikatakan bahwa siswa yang mempunyai motivasi dalam dirinya akan lebih mudah mengikuti dan akan lebih menyukai meteri pembelajaran. Karena siswa yang memlki motivasi dalam dirinya akan memiliki usaha yang kuat dan gigih untuk menyelesaikan masalah pembelajaran yang dihadapinya. Dan perlu juga diketahu bahwa setiap siswa atau individu mempunyai karakteristik yang berbeda-beda.

\section{Hasil Belajar Pelestarian Lingkungan Hidup}

Belajar adalah proses seseorang memperoleh berbagai perubahan keterampilan dan sikap, oleh karena itu belajar merupakan tindakan dan perilaku siswa yang kompleks, yang hanya dialami oleh siswa itu sendiri. Menurut Higard dan Bower (dalam Sagala, 2007:51) belajar merupakan perubahan tingkah laku yang relatif permanen dan yang merupakan hasil proses pembelajaran bukan disebabkan adanya proses kedewasaan. Sementara Sudjana (2001:8) menjelaskan bahwa belajar dapat ditinjau dari dua segi yaitu belajar sebagai proses dan belajar sebagai hasil. Selanjutnya Gagne dan Barliner (1979:98) berpendapat belajar sebagai hasil adalah perubahan tingkah laku yang diperoleh dari kegiatan belajar.

Sabri (2010:19) mengemukakan belajar adalah proses perubahan perilaku berkat pengalaman dan pelatihan. Artinya tujuan kegiatan belajar ialah perubahan tingkah laku, baik yang menyangkut pengetahuan, keterampilan, sikap, bahkan meliputi segenap aspek pribadi. Perubahan tersebut bersifat intensional, positif-aktif dan efektif fungsional. (1) Perubahan intensional yaitu perubahan yang 
terjadi karena pengalaman atau prktek yang dilakukan, proses belajar dengan sengaja dan disadari, bukan terjadi secara kebetulan; (2) Perubahan yang bersifat positif-aktif yaitu perubahan yang bermanfaat sesuai dengan harapan pelajar, disamping menghasilkan sesuatu yang baru dan lebih baik dibandingkan sebelumnya, sedangkan perubahan yang bersifat aktif yaitu perubahan yang terjadi karena usaha yang dilakukan pelajar, bukan terjadi sendirinya; (3) Perubahan yang bersifat efektif yaitu perubahan yang memberikan pengaruh dan manfaat bagi pelajar. Adapun yang bersifat fungsional yaitu perubahan yang relatif tetap serta dapat diproduksi atau dimanfaatkan setiap kali dibutuhkan.

Geografi adalah pelajaran IPS khusus mempelajarai tentang gejala alam dan kehidupan di muka bumi sertainteraksi antara manusia dengan lingkungan dalam kaitannya dengan aspek keruangan dan waktu. Menurut Wardiyatmoko (2006:1) dikatakan ada tiga fungsi mata pelajaran geografi yaitu (1) mengembangkan pengetahuan tentang polapola keruangan dan proses yang berkaitan; (2) mengembangkan keterampilan dasar dalam memperoleh data dan informasi, mengkomunikasikan, serta menerapkan pengetahuan geografi untuk kepentingan pembangunan; dan (3) menumbuhkan sikap, kesadaran, dan kepedukian terhadap lingkungan hidup dan sumber daya serta toleransi keragaman soisal budaya masyarakat.

Menurut Yusman Hestianto (2010:77) lingkungan hidup merupakan suatu sistem kesatuan ruang bagi mahluk hidup dan komponen abiotik yang ada di dalamnya. Selanjutnya dikatakan hubungan timbal balik yang saling menguntungkan antara makhluk hidup dan komponen abiotik yang ada membentuk sebuah ekosistem. Sedangkan menurut Emil Salim (dalam Darsono, 1995:68) lingkungan hidup adalah segala benda, kondisi, keadaan dan pengaruh yang terdapat dalam ruangan yang kita tempati dan mempengaruhi hal yang hidup termasuk kehidupan manusia.

Untuk mengatasi pencemaran lingkungan, manusia perlu melestarikan lingkungan hidup. Menurut Wardiyatmoko (2006:137) pelestarian lingkungan hidup adalah rangkaian upaya untuk melindungi kemampuan lingkungan hidup terhadap tekanan perubahan dan dampak negatif yang ditimbulkan oleh suatu kegiatan agar tetap mampu mendukung kehidupan manusia dan makhluk hidup lainnya.
Ada beberapa upaya pelestarian lingkungan hidup, antara lain: (1) upaya pelestarian hutan, yaitu dilakukan melalui tata guna lahan, peraturan Tebang Pilih Taman Indonesia, reboisasi, dan system tumpang sari pada pertanian; (2) upaya peletraian keanekaragaman hayati, yaitu peletarian varietas asli tanaman; (3) upaya peletarian tanah dan sumber daya air, yaitu dilakukan dengan cara pencegahan pencemaran, pengamanan pintu-pintu air, dan penggunaan air tidak boros; dan (4) upaya pelestarian sumber daya udara, yaitu pencegahan dikakukan terhadap pabrik dengan melakukan penyaringan terhadap pembuangan gas, penanaman pohon-pohon pembatas jalan raya dan hutan kota sebagai paru-paru kota, serta melakukan uji emisi buangan gas terhadap kendaraan bermotor.

Dalam pemanfaatan lingkungan sebagai penopang pembangunan harus pula memperhitungkan keterbatasannya, sehingga tidak boleh serakah agar tidak habis pada saat ini. Menurut Hestiyanto (2010:94) Dalam Pelestarian lingkungan ada beberapa nilai dasar yang perlu diperhartikan, yaitu; (1) dilaksanakan berdasarkan konsep pembangunan berkelanjutan, yaitu pembangunan yang memenuhi aspirasi dan kebutuhan manusia saat ini tanpa mengurangi potensi pemenuhan kebutuhan manusia pada generasi mendatang, pembangunan juga didasarkan atas kesejahteraan masyarakat serta keadilan dalam jangka waktu pendek menengah dan panjang dengan keseimbangan pertumbuhan e3konomi, dinamika social dan pelestarian lingkungan hidup; (2) dilestarikan demi kepentingan manusia baik dalam jangka pendek, menengah maupun jangka panjang. Didalam upaya pelestarian lingkungan, usaha penceganhan lebih diutamakan daripada usaha penanggulangan dan pemulihan; (3) pemanfaatan sumber daya alam yang tidak dapat diperbaharui perlu memperhatikan kebutuhan antara generasi. Sedangkan pemanfaatan sumber daya alam yang dapat diperbaharui perlu memeperhatikan daya pemulihannya; (4) setiap warga Negara mempunyai hak untuk mendapatkan lingkungan yang baik dan sehat tetapi berkewajiban untuk melestarikan lingkungan tersebut; dan (5) kualitas lingkungan ditetapkan berdasarkan fungsinya. Pencemaran dan perusakan lingkungan perlu dihinari.

Sementara itu Wardiyatmoko, (2006:140) menjelaskan ciri-ciri pembangunan 
berwawasan lingkungan dan pembangunan berkelanjutan adalah: (1) menggunakan pendekatan integratif maka keterkaitan yang kompleks antar manusia dengan lingkungan dapat dimungkinkan untuk masa kini dan masa yang akan datang; (2) menggunakan pandangan jangka panjang, untuk merencakan pengelolaan dan pemanfaatan sumber daya yang mendukung pembangunan agar secara berkelanjutan dapat digunakan dan dimanfaatkan; (3) menjamin pemerataan dan keadilan, strategi pembangunan yang berwawasan lingkungan dilandasi oleh pemerataan distribusi lahan dan faktor produksi, pemerataan kesempatan perempuan, dan pemeratan ekonomi untuk kesejahteraan; dan (4) menghargai keanekaragaman hayati, yang merupakan dasar bagi tatanan lingkungan. Pemeliharaan keanekaragaman hayati memiliki kepastian bahwa sumber daya alam selalu tersedia untuk masa kini dan masa yang datang.

\section{Starategi Pembelajaran}

Menurut Morrison (1994:119) bahwa strategi pembelajaran merupakan urutan/langkah pengajaran untuk mencapai tujuan pengajaran yang telah ditetapkan. Selanjutnya Seels dan Rehey mendefinisikan strategi pembelajaran sebagai spesifikasi pemilihan dan pengurutan kegiatan dalam suatu pengajaran pelajaran tertentu. Penetuan strategi embejaran didasarkan atas tujuan-tujuan yang sudah tetuang dalam rencana program pebelajaran.

Sedangkan Dick and Carey (2015:162) mendefinisikan strategi pembelajaran sebagai komonen umum dari suatu set bahan pengajaran dan prosedur yang dugunakan berkaitan dengan bahan tersebut untukmencapai tujuan pengajaran yang telah ditetapkan. Selanjutnya Miarso (2005:536) menyebutkan bahwa strategi pembelajaran adalah pendekatan pembelajaran secara menyeluruh dalam suatu system pembelajaran, yang berupa pedoman umum dan kerangka kegiatan untuk mencapai tujuan. Sedangkan Hamalik (2004:89) menambahkan bahwa strategi pembelajaran adalah sebagai sistim menyeluruh yang terdiri dari sejumlah komponen yaitu komponen masukan atau input, komponen proses dan komponen produk atau out-put.

$$
\begin{aligned}
& \text { Menurut Sanjaya } \\
& \text { menyebutkan bahwa suatu } \begin{array}{r}
(2007: 68) \\
\text { strategi }
\end{array} \\
& \text { pembelajaran yang diterapkan guru akan } \\
& \text { tergantung pada pendekatan yang dugunakan, } \\
& \text { sedangkan bagaimana menjalankan strategi itu }
\end{aligned}
$$

dapat ditetapkan dengan berbagai metode pembelajaran. Selanjutnya Uno (2006:143) menjelaskan bahwa karakteristik siswa merupakan salah satu hal yang perlu diidentifikasikan oleh guru untuk digunakan sebagai petunjuk dalam mengembangkan program pembelajaran, karakeristik tersebut dapat berupa bakat, motivasi, gaya belajar, kemampuan berfikir, minat, sikap, kemapuan awal, kecerasan dan lain sebagainya. Dengan demikian dapat dikatakan bahwa seorang guru ketika menyampaikan informasi pembelajaran kepada siswa dengan menggunakan strategi yang sesuai dengan tujuan yang ingin dicapai dan sifat atau karakteristik anak didiknya.

Merril (1981) Mengklasifikasikan strategi pembelajaran atas tiga dasar yaitu: (1) tujuan pengajaran meliputi kombinasiantara jenis materi dan tingkah laku yang duharapkan; (2) cara mempresentasekan materi yaitu dari tingkat yang khusus ke tingkat umum atau sebaliknya; dan (3) bentuk respon peserta didik dibedakan atas bentuk ekspositori dan inkuiri. Hal ini didukung dengan pendapat Romizowiski (1981:89) menekankan bahwa setiap strategi pembelajaran yang dikembangkan selalu mencerminkan posisi teoritis yang dianaut tentang bagaimana seharusnya pembelajaran itu dilakukan.

Strategi inkuiri adalah merupakan bagian dari pembelajaran kontekstual. Hal ini sesuai dengan apa yang dikemukakan Trianto (2010:107) mengemukakan bahwa pembelajaran kontektual adalah konsep belajar yang membantu guru mengaitkan antara materi yang diajarkannya dengan situasidunia nyata siswa dan mendorong siswa membuat hubungan antara pengetahuan yang dimilikinya dengan penerapannya dalam kehidupan mereka sehari-hari, dengan melibatkan tujuh komponen utama pembelajaran kontekstual, yaitu : Konstruktivisme (constructivism), bertanya (questioning), inkuiri (inquiry), masyarakat belajar (learning community), pemodelan (modeling), dan penilaian autentik (authentic assessment)

\section{Hakikat Strategi Pembelajaran Ekspositori}

Strategi pembelajaran ekspositori adalah strategi pembelajaran yang menekankan kepada proses penyampaian materi secara verbal dari seorang guru kepada sekelompok siswa dengan maksud agar siswa dapat menguasai materi pelajaran secara optimal. Roy Killen dalam (Sanjaya, 2007:177) menamakan 
strategi ekspositori ini dengan istilah strategi pembelajaran langsung (direct insructioni). Dalam strategi ini materi pelajaran disampaikan langsung oleh guru. Siswa tidak dituntut untuk menemukan materi itu. Materi pelajaran seakan-akan sudah jadi. Oleh karena strategi ekspositori lebih menekankan kepada proses bertutur, maka sering juga dinamakan istilah strategi "chalk and talk"

Hakikat Strategi Pembelajaran Inkuiri (SPI)

Strategi pembelajaran inkuiri (SPI) atau yang biasa disebut startegi menemukan. Pengetahuan dan keterampilan yang diperoleh siswa diharapkan bukan hanya hasil mengingat seperangkat fakta-fakta, tetapi juga hasil dari menemukan sendiri. Menurut Sanjaya (2007:193) menyatakan bahwa strategi inkuiri adalah rangkaian kegiatan pembelajaran yang menekankan pada proses berpikir secara kritis dan analitis untuk mencari dan menemukan sendiri jawaban dari suatu masalah yang dipertanyakan. Proses berpikir itu sendiri biasanya dilakukan melalui Tanya jawab antara guru dan siswa. Strategi pembelajaran ini sering juga dinamakan strategi heuristic, yang berasal dari bahasa Yunani, yaitu heuriskein yang berarti saya menemukan.

SIP berangkat dari asumsi bahwa sejak manusia lahir ke dunia, manusia memiliki dorongan untuk menemukan sendiri pengetahuannya. Rasa ingin tahu tentang keadaan alam di sekelilingnya merupakan kodrat manusia sejak ia lahir ke dunia. Sejak kecil manusia memiliki keinginan untuk mengenal segala sesuatu melalui indra pengecapan, pendengaran, penglihatan dan indra-indra lainnya. Hingga dewasa keingintahuan manusia secara terus-menerus berkembang dengan menggunakan otak dan pikirannya. Pengetahuan yang dimiliki manusia akan bermakna (meaningfull) manakala didasari oleh keingintahuan itu. Dalam rangka itulah strategi inkuiri dikembangkan.

Ada beberapa hal yang menjadi ciri utama strategi pembelajaran inkuiri, pertama, strategi inkuiri menekankan kepada aktivitas siswa secara maksimal untuk mencari dan menemukan, artinya strategi inkuiri menempatkan siswa sebagai subjek belajar. Dalam proses pembelajaran, siswa tidak hanya berperan sebagai penerima pelajaran melalui penjelasan guru secara verbal, tetapi mereka berperan untuk menemukan sendiri inti dari materi pelajaran itu sendiri.
Kedua, seluruh aktivitas yang dilakukan siswa diarahkan untuk mencari dan menemukan jawaban sendiri dari sesuatu yang dipertanyakan, sehingga diharapkan dapat menumbuhkan sikap percaya diri (self belief). Dengan demikian, strategi pembelajaran inkuiri menempatkan guru bukan sebagai sumber belajar, akan tetapi sebagai fasilitator dan motivator belajar siswa. Aktivitas pembelajaran biasanya dilakukan melalui proses Tanya jawab antara guru dan siswa. Oleh sebab itu kemampuan guru dalam menggunakan teknik bertanya merupakan syarat utama dalam melakukan inkuiri.

Ketiga, tujuan dari penggunaan strategi pembelajaran inkuiri adalah mengembangkan kemampuan berpikir secara sistematis, logis dan kritis, atau mengembangkan kemampuan intelektual sebagai bagian dari proses mental. Dengan demikian, dalam strategi pembelajaran inkuiri siswa tak hanya dituntut agar menguasai materi pelajaran, akan tetapi bagaimana mereka dapat menggunakan potensi yang dimilikinya. Manusia yang hanya menguasai pelajaran belum tentu dapat mengembangkan kemampuan berpikir secaara optimal; namun sebaliknya, siswa akan dapat mengembangkan kemampuan berpikirnya manakala ia bisa menguasai materi pelajaran.

\section{Motivasi Brprestasi}

Istilah motivasi (motivation) atau motif (motive) populer di dalam dunia kehidupan yang menuntut prestasi. Menurut Sardiman (2004:2) Motivasi " adalah sebagai kekuatan, dorongan, kebutuhan, semangat, tekanan, atau mekanisme psikologi yang mendorong seseorang atau sekelompok orang untuk mencapai prestasi tertentu sesuai dengan apa yang dikehendaki". Selanjutnya Usman (2006:223) menjelaskan motivasi ialah keinginan untuk berbuat sesuatu, sedangkan motif adalah kebutuhan (need), keinginan (wish), dorongan (desire) atau impuls. Motivation berarti pemberian motif, penimbunan motif atau hal yang menimbulkan dorongan atau keadaan yang menimbulkan dorongan. Dengan demikian dapat dikatakan bahwa adalah suatu kondisi yang memberikan dorongan dari dalam diri seseorang yang digambarkan sebagai keinginan atau kemauan untuk mencapai sesuatu yang diinginkan.

Sedangkan Motivasi berprestasi adalah keinginan atau dorongan dari dalam diri untuk menyelesaikan suatu tantangan dan hambatan 
dalam upaya mewujudkan tujuan yang ingin di capai. Menurut McClelland (dalam Husaini, 2006: 259) seseorang dianggap mempunyai motivasi untuk berprestasi jika ia mempunyai keinginan untuk melakukan suatu karya yang berprestasi lebih baik dari prestasi karya orang lain. Seseorang dengan suatu kebutuhan yang kuat akan termotivasi untuk menggunakan tingkah laku yang sesuai guna memuaskan kebutuhannya. Sementara Maslow`s and Herzberg`s (dalam Mathias dan Jackson, 2006:268) mengemukakan terdapat lima tingkat kebutuhan manusia yang paling rendah sampai pada kebutuhan yang paling tinggi, yaitu: (1) kebutuhan fisiologikal (fisiogoical needs); (2) kebutuhan keselamatan (safety needs); (3) kebutuhan berkelompok (social needs); (4) kebutuhan penghargaan (esteem needs); dan (5) kebutuhan aktualisasi diri (self actualization).

Menurut McClelland, dalam Thoha (2009: 236) ada sejumlah karakteristik orang yang berprestasi tinggi yaitu: (1) Berani mengambil resiko moderat (moderate risks). Resiko moderat artinya adalah resiko yang berada di antara resiko tertinggi dan resiko terendah. Pekerja yang terlalu berani mengambil resiko biasanya bekerja secara rambang saja. Sebaliknya, pekerja yang tidak mau ambil resiko biasanya hanya ikut arus atau tidak mempunyai prakarsa; (2) Menghendaki umpan balik segera (immediate feedback). Pekerja yang mempunyai motivasi berprestasi tinggi segera menghendaki umpan balik dari hasil pekerjaannya. Informasi yang dia dapatkan digunakan untuk meningkatkan prestasinya menjadi lebih baik. Umpan balik positif tidak membuatnya terlena dan umpan balik negatif tidak menimbulkan frustasi yang berlebihan. Baik kelebihan maupun kekurangan dimanfaatkan untuk keperluan meningkatkan prestasi lebih dari kondisi sekarang; (3) Keberhasilan diperhitungkan secara teliti. Tipe pekerja seperti ini lebih mementingkan pencapaian tugas dibebankan kepadanya tanpa memperhitungkan secara berlebihan imbalan apa yang akan diperoleh. Dia lebih puas dengan segi-segi intrinsik pekerjaan daripada materi atau hadiah istimewa. Segala aspek materil hanya merupakan efek sampingan saja dari prestasi yang dicapainya; (4) Mengintegralkan dengan tugas. Pekerja yang motivasi berprestasinya tinggi menerima tugas sebagai bagian dari hidupnya. Tugas-tugas atau pekerjaan (order) yang dihadapi atau dilimpahkan kepadanya tidak dipandang sebagai beban akan tetapi dilihat sebagai kewajaran. Kata hatinya mengatakan bahwa "saya memang harus berbuat begitu", bukan "beban saya terlalu berat dan tidak adil". Kata lainnya, sikap yang ditampilkan oleh individu itu mengintegral dengan tugas-tugasnya. Orangorang seperti ini biasanya bersikap tidak sengaja menunda separo pekerjaan, bersahabat, realistik, dan mengutamakan kemampuan individual.

$$
\text { Sedangkan Husaini (2006:260) }
$$
mengemukakan orang yang motif berprestasinya tinggi bercirikan: (1) bertanggung jawab atas segala perbuatannya; (2) berusaha mencari umpuan balik atas segala perbuatannya; (3) berani mengambil resiko dengan penuh perhitungan melebihi orang lain; (4) berusaha melakukan sesuatu secara inovatif dan kreatif; (5) merasa dikejar-kejar waktu; dan (6) bekerja keras dan bangga atas hasil yang telah dicapai.

Motif seseorang dalam melaksanakan tugasnya berbeda setiap orang. Sutrisno (2009:114) menyebutkan motif terdiri dari dua unsur, yaitu unsur pertama, berupa daya dorong untuk berbuat, dan unsur yang kedua ialah sasaran atau tujuan yang akan diarahkan oleh perbuatan itu. Dua unsur dalam motif ini membuat orang melakukan kegiatan sekaligus ingin mencapai apa yang dikehendaki melalui kegiatan yang dilakukan itu.

Pada dasarnya ada tiga karakteristik pokok motivasi menurut Sopiah (2008:169), yaitu: (1) Usaha, yakni menunjukkan kepada kekuatan perilaku kerja seseorang atau jumlah yang ditunjukkan oleh seseorang dalam pekerjaannya. Tegasnya, hal ini melibatkan berbagai macam kegiatan atau upaya baik yang nyata maupun yang kasat mata; (2) Kemauan Keras, yang ditunjukkan oleh seseorang ketika menerapkan usahanya kepada tugas-tugas pekerjaannya. Dengan kemauan yang keras, maka segala usaha akan dilakukan. Kegagalan tidak akan membuatnya patah arang untuk terus berusaha samapai tercapainya tujuan; (3) Arah atau Tujuan, berkaiatan dengan arah yang dituju oleh usaha dan kemauan keras yang dimiliki oleh seseorang.

Di sisi lain motivasi berprestasi dapat berpengaruh terhadap hasil produktifitas ataupun kinerja seseorang. Seperti yang dikemukakan oleh Handoko (2001:193) bahwa seseorang bekerja dengan produktif atau tidak, tergantung kepada : motivasi, kepuasan kerja, tingkat stres, kondisi fisik pekerjaan, sistem 
kompensasi, desain pekerjaan, dan aspek-aspek ekonomis serta keperilakuan lainnya. Menurut Gibson (1997:113) menjelaskan seseorang yang mempunyai motivasi berprestasi akan mempunyai perilaku seperti: (1) lebih suka menetapkan sendiri tujuan prestasinya; (2) lebih suka menghindari tujuan prestasi yang mudah dan sukar, artinya mereka lebih menyukai tujuan yang sesuai dengan kemampuan mereka; (3) lebih menyukai balikan yang cepat dan efisien mengenai prestasi mereka; dan (4) lebih bertanggung jawab terhadap pemecahan masalah.

Selanjutnya menurut Hamzah (2007:69) ada dua faktor penentu perlu tidaknya seseorang diberikan motivasi, yakni: (1) kebutuhan, seorang akan termotivasi untuk melakukan kegiatan atau pekerjaan apabila ia mengetahui bahwa ada kebutuhan yang belum terpenuhi. Dengan bekerja, satu kebutuhan terpenuhi dapat terpuaskan; (2) pengaruh perilaku, yaitu para siswa sepakat bahwa karena dipengaruhi oleh kebutuhan, siswa akan mengarahkan perilaku mereka ke arah pencapaian tujuan tersebut. Siswa yang merasa kebutuhannya tidak terpuaskan, berusaha untuk memuaskan dengan cara mengarahkan perilakunya sehingga tujuan (kepuasan) dapat dicapai.

Rumusan masalah adalah sebagai berikut: (1) Apakah kelompok siswa yang diajar dengan strategi pembelajaran inkuiri memperoleh hasil belajar pelestarian lingkungan hidup lebih tinggi dibandingkan dengan kelompok siswa yang diajar dengan strategi pembelajaran ekspositori?; (2) Apakah kelompok siswa yang memiliki motivasi berprestasi tinggi memperoleh hasil belajar pelestarian lingkungan hidup lebih tinggi dibandingkan dengan kelompok siswa yang memiliki motivasi berprestasi rendah?; dan (3) Apakah terdapat interaksi antara strategi pembelajaran dan motivasi berprestasi siswa terhadap hasil belajar pelestarian lingkungan hidup?

\section{METODE}

Penelitian ini dilaksanakan di Negeri Paranginan dan SMA Lintong Nihuta kelas XI SMA Kabupaten Humbang Hasundutan. Populasi penelitian ini adalah seluruh siswa kelas XI Jurusan IPS SMA Negeri Paranginan dan SMA Negeri Lintong Nihuta, yang terdiri 3 kelas di SMA Paranginan, yaitu kelas XI IPS 1 berjumlah 42 orang, IPS 2 berjumlah 42 orang, dan IPS 3 berjumlah 42 orang dan 4 Kelas di SMA Negeri Lintong Nihuta yaitu kelas XI IPS 1 berjumlah 42 orang, IPS 2 berjumlah 42 orang, IPS 3 berjumlah 42 dan IPS 4 berjumlah 42 orang sehingga total populasi adalah 294 orang. Dalam hal ini diambil 2 kelas sebagai sampel penelitian, yaitu satu kelas dari SMA Negeri Paranginan dan satu kelas dari SMA Lintong Nihuta Teknik yang dipergunakan adalah pengambilan sampel secara acak (cluster random sampling) atau dengan teknik undian.

Penelitian ini menggunakan metode eksperimental semu (quasi-eksperimental research). Adapun desain penelitian yang digunakan seperti pada tabel di bawah ini:

Tabel 1. Desain Faktorial $2 \times 2$

\begin{tabular}{|c|c|c|}
\hline $\begin{array}{c}\text { Strategi pembelajaran } \\
\text { Motivasi Berprestasi }\end{array}$ & $\begin{array}{c}\text { Ekspositori } \\
\text { (A1) }\end{array}$ & $\begin{array}{c}\text { Inkuiri } \\
\text { (A2) }\end{array}$ \\
\hline Tinggi (B1) & A1B1 & A2B1 \\
\hline Rendah (B2) & A1B2 & A2B2 \\
\hline
\end{tabular}

Keterangan :

$\mathrm{A}=$ Strategi Pembelajaran

$\mathrm{B}=$ Motivasi Berprestasi Siswa

A1 = Strategi Pembelajaran Ekspositori

A2 = Strategi Pembelajaran Inkuiri

B1 = Kelompok siswa memiliki motivasi berprestasi tinggi

B2 = Kelompok siswa memiliki motivasi berprestasi rendah
A1B1 = Hasil belajar kelompok siswa motivasi berprestasi tinggi dengan perlakuan strategi pembelajaran ekspositori

$\mathrm{A} 2 \mathrm{~B} 1=$ Hasil belajar kelompok siswa motivasi berprestasi tinggi dengan perlakuan strategi pembelajaran inkuiri

A1B2 = Hasil belajar kelompok siswa motivasi berprestasi rendah dengan 
perlakuan strategi pembelajaran ekspositori.

A2B2 = Hasil belajar kelompok siswa motivasi berprestasi rendah dengan perlakuan strategi pembelajaran inkuiri.

Teknik analisis data yang digunakan adalah teknik statistik deskriptif dan inferensial. Teknik statistik deskriptif digunakan untuk mendeskripsikan data antara lain: nilai rata-rata (mean), standard deviasi, median, dan modus, kemudian disusun dalam daftar distribusi frekwensi serta dalam bentuk bagan. Selanjutnya digunakan untuk menentukan kecenderungan masing-masing variabel rumus yang digunakan menurut Sudjana (2005:18). Teknik statistik inferensial digunakan untuk menguji hipotesis penelitian, dimana teknik inferensial yang digunakan adalah teknik analisis varians Anava 2 jalur (desain faktorial 2 × 2 dengan taraf signifikansi 0.05 .

Untuk melihat kelompok sampel yang lebih baik dari kelompok-kelompok sampel ANAVA dimana banyak datanya sama untuk setiap kelompok, maka perlu dilakukan uji lanjut dengan menggunakan Uji-Tuckey dengan rumus:

$$
F=\frac{\left|\bar{X}_{1}-\bar{X}_{j}\right|}{\sqrt{\frac{M S_{\text {eror }}}{N}}}
$$

Jika $F_{\text {hitung }}>F_{\text {tabel }}$ maka dapat dinyatakan ada perbedaan yang signifikan.

\section{Hipotesis Penelitian}

Adapun hipotesis yang diuji dalam penelitian ini adalah sebagai berikut :

Pertama $\mathrm{H} 0: \mu \mathrm{A} 1=\mu \mathrm{A} 2 \quad$; Ha $: \mu \mathrm{A} 1>$ $\mu \mathrm{A} 2$

Kedua $\quad$ H0 $: \mu \mathrm{B} 1=\mu \mathrm{B} 2 \quad ; \mathrm{Ha}: \mu \mathrm{B} 1>$ $\mu \mathrm{B} 2$

Ketiga $\quad \mathrm{H} 0: \mathrm{Mm}><\mathrm{Ed}=0$; $\mathrm{Ha}: \mathrm{Mm}><$ $\mathrm{Ed} \neq 0$

H0 : Hipotesis Nol

$\mathrm{Ha} \quad$ : Hipotesis Alternatif

$\mathrm{A} 1$ : Rata-rata hasil belajar pelestarian lingkungan hidup dengan perlakuan strategi pembelajaran ekspositori

$\mu \mathrm{A} 2$ : Rata-rata hasil belajar pelestarian lingkungan hidup dengan perlakuan strategi pembelajaran inkuiri

$\mu \mathrm{B} 1$ : Rata-rata hasil belajar pelestarian lingkungan hidup siswa yang mempunyai motivasi berprestasi tinggi

$\mu \mathrm{B} 2$ : Rata-rata hasil belajar pelestarian lingkungan hidup siswa yang mempunyai motivasi berprestasi rendah

$\mathrm{Mm} \quad$ : Strategi pembelajaran

Ed : Motivasi berprestasi

\section{HASIL DAN PEMBAHASAN \\ Hasil}

Pengujian hipotesis dilakukan dengan menggunakan teknik analisis Varians (ANAVA).

Tabel 2. Rangkuman Data Hasil Penelitian

\begin{tabular}{|c|c|c|c|c|}
\hline \multirow{2}{*}{\multicolumn{2}{|c|}{ Variabel }} & \multicolumn{2}{|c|}{ Gaya Mengajar } & \multirow{2}{*}{ Total } \\
\hline & & Inkuiri & Ekspositori & \\
\hline \multirow{2}{*}{$\begin{array}{l}\text { Motivasi } \\
\text { Berprestasi }\end{array}$} & Tinggi & $\begin{array}{l}\mathrm{N}=22 \\
\bar{X}=76,95 \\
\sum \mathrm{X}=1.693 \\
\sum \mathrm{X}^{2}=131.657\end{array}$ & $\begin{array}{l}\mathrm{N}=20 \\
\bar{X}=66,00 \\
\sum \mathrm{X}=1.452 \\
\sum \mathrm{X}^{2}=106.232\end{array}$ & $\begin{array}{l}\mathrm{N}=42 \\
\bar{X}=74,88 \\
\sum \mathrm{X}=3.295 \\
\sum \mathrm{X}^{2}=237.889\end{array}$ \\
\hline & Rendah & $\begin{array}{l}\mathrm{N}=20 \\
\bar{X}=64,09 \\
\sum \mathrm{X}=1.410 \\
\sum \mathrm{X}^{2}=100.270\end{array}$ & $\begin{array}{l}\mathrm{N}=22 \\
\bar{X}=73,91 \\
\sum \mathrm{X}=1.626 \\
\sum \mathrm{X}^{2}=121.220\end{array}$ & $\begin{array}{l}\mathrm{N}=42 \\
\bar{X}=72,28 \\
\sum \mathrm{X}=3.036 \\
\sum \mathrm{X}^{2}=221.490\end{array}$ \\
\hline \multicolumn{2}{|c|}{ Total } & $\begin{array}{l}\mathrm{N}=42 \\
\bar{X}=73,93 \\
\sum \mathrm{X}=3.103 \\
\sum \mathrm{X}^{2}=231.927\end{array}$ & $\begin{array}{l}\mathrm{N}=42 \\
\bar{X}=73,29 \\
\sum \mathrm{X}=3.078 \\
\sum \mathrm{X}^{2}=227.452\end{array}$ & $\begin{array}{l}\mathrm{N}=84 \\
\bar{X}=73,58 \\
\sum \mathrm{X}=6.181 \\
\sum \mathrm{X}^{2}=459.379\end{array}$ \\
\hline
\end{tabular}

Tabel 3. Hasil Perhitungan ANAVA 


\begin{tabular}{|c|c|c|c|c|c|}
\hline Sumber Varians & $\begin{array}{c}\text { Jumlah } \\
\text { Kuadrat }(\mathrm{JK})\end{array}$ & $\mathrm{Dk}$ & $\begin{array}{c}\text { Rata-rata Jumlah } \\
\text { Kuadrat (RJK) }\end{array}$ & $\mathrm{F}_{\text {hitung }}$ & $\begin{array}{c}\mathrm{F}_{\text {tabel }(\alpha=0,05)} \\
(1: 84)\end{array}$ \\
\hline Antar Kolom & 207,44 & 1 & 207,44 & 5,42 & 3,96 \\
Antar Baris & 341,44 & 1 & 341,44 & 8,92 & 3,96 \\
Interaksi & $1.112,97$ & 1 & $1.112,97$ & 29,09 & 3,96 \\
\hline Antar Kelompok & $1.661,85$ & 3 & 553,95 & - & - \\
Dalam Kelompok & $3.098,57$ & 81 & 38,25 & - & - \\
\hline Total & $4.760,42$ & 84 & - & - & - \\
\hline
\end{tabular}

Hasil Belajar Pelestarian Lingkungan Hidup yang Diajar dengan Strategi Inkuiri Lebih Tinggi dari Hasil Belajar Siswa yang Diajar dengan Strategi Ekspositori

Untuk menguji apakah hasil belajar pelestarian lingkungan hidup yang diajar dengan strategi inkuiri berbeda dari pada hasil belajar pelestarian lingkungan hidup yang diajar dengan strategi ekspositori, maka digunakan teknik analisis varians (ANAVA).

Dari hasil perhitungan dengan ANAVA diperoleh bahwa $F_{\text {hitung }}=5,42$ dan $\mathrm{F}_{\text {tabel }}=3,96$ pada taraf signifikansi 0,05. hal ini berarti bahwa $F_{\text {hitung }}>F_{\text {tabel }}$, menunjukkan bahwa hipotesis nol $\left(\mathrm{H}_{0}\right)$ ditolak dan hipotesisi alternatif $\left(\mathrm{H}_{\mathrm{a}}\right)$ diterima. Dengan demikian bahwa hipotesisi penelitian yang menyatakan hasil belajar pelestarian lingkungan hidup yang diajar dengan strategi inkuiri berbeda dengan hasil belajar pelestarian lingkungan hidup yang diajar dengan strategi ekspositori teruji kebenarannya. Berdasarkan data yang diperoleh juga menunjukkan bahwa nilai ratarata hasil belajar pelestarian lingkungan hidup yang diajar dengan strategi inkuiri lebih tinggi daripada hasil belajar pelestarian lingkungan hidup yang diajar dengan strategi ekspositori.

Perbandingan nilai rata-rata dan pengujian ANAVA yang diperoleh dapat disimpulkan hasil belajar pelestarian lingkungan hidup yang diajar dengan strategi inkuiri berbeda dengan hasil belajar pelestarian lingkungan hidup yang diajar dengan strategi ekspositori.

\section{Hasil Belajar Pelestarian Lingkungan Hidup yang Memiliki Motivasi berpestasi Tinggi Lebih Tinggi dari Siswa yang Memiliki Efikasu Rendah}

Pengujian apakah hasil belajar pelestarian lingkungan hidup yang memiliki motivasi berpestasi tinggi berbeda dengan hasil belajar pelestarian lingkungan hidup yang memiliki motivasi berpestasi rendah, juga dilakukan dengan menggunakan teknik analisis varians (ANAVA).

Dari hasil perhitungan dengan ANAVA diperoleh bahwa $F_{\text {hitung }}=8,92$ dan $\mathrm{F}_{\text {tabel }}=3,96$ pada taraf signifikansi 0,05 . hal ini berarti bahwa $\mathrm{F}_{\text {hitung }}>\mathrm{F}_{\text {tabel}}$, menunjukkan bahwa hipotesis nol $\left(\mathrm{H}_{0}\right)$ ditolak dan hipotesisi alternatif $\left(\mathrm{H}_{\mathrm{a}}\right)$ diterima. Dengan demikian bahwa hipotesis penelitian yang menyatakan hasil belajar pelestarian lingkungan hidup yang memiliki motivasi berpestasi tinggi tinggi berbeda dengan hasil belajar pelestarian lingkungan hidup yang memiliki motivasi berpestasi rendah teruji kebenarannya. Berdasarkan data yang diperoleh juga menunjukkan bahwa nilai rata-rata hasil belajar siswa yang memiliki motivasi berpestasi tinggi lebih tinggi daripada hasil belajar siswa yang memiliki motivasi berpestasi rendah.

Perbandingan nilai rata-rata dan pengujian ANAVA yang diperoleh dapat disimpulkan hasil belajar pelestarian lingkungan hidup yang memiliki motivasi berpestasi tinggi berbeda dengan hasil belajar pelestarian lingkungan hidup yang memiliki motivasi berpestasi rendah.

\section{Interaksi Antara Strategi Mengajar Dengan Motivasi Berpestasi}

Pengujian ada tidaknya interaksi antara strategi dengan motivasi berpestasi dalam mempengaruhi hasil belajar pelestarian lingkungan hidup juga dilakukan dengan menggunakan teknik analisis varians (ANAVA).

Dari hasil perhitungan dengan ANAVA. diperoleh bahwa $F_{\text {hitung }}=29,09$ dan $\mathrm{F}_{\text {tabel }}=3,96$ pada taraf signifikansi 0,05 . Hal ini berarti bahwa $F_{\text {hitung }}>F_{\text {tabel}}$, menunjukkan bahwa hipotesis nol $\left(\mathrm{H}_{0}\right)$ ditolak dan hipotesisi alternatif $\left(\mathrm{H}_{\mathrm{a}}\right)$ diterima. Dengan demikian bahwa hipotesis penelitian yang menyatakan terdapat interaksi antara strategi dengan motivasi berpestasi dalam mempengaruhi hasil 
belajar pelestarian lingkungan hidup teruji kebenarannya.

Berdasarkan hasil pengujian hipotesis di atas dapat juga dilihat bahwa ada interaksi antara strategi mengajar dengan motivasi berpestasi terhadap hasil belajar pelestarian lingkungan hidup. Interaksi antara strategi mengajar dengan motivasi berpestasi dapat dilihat pada Gambar 1 di bawah ini:

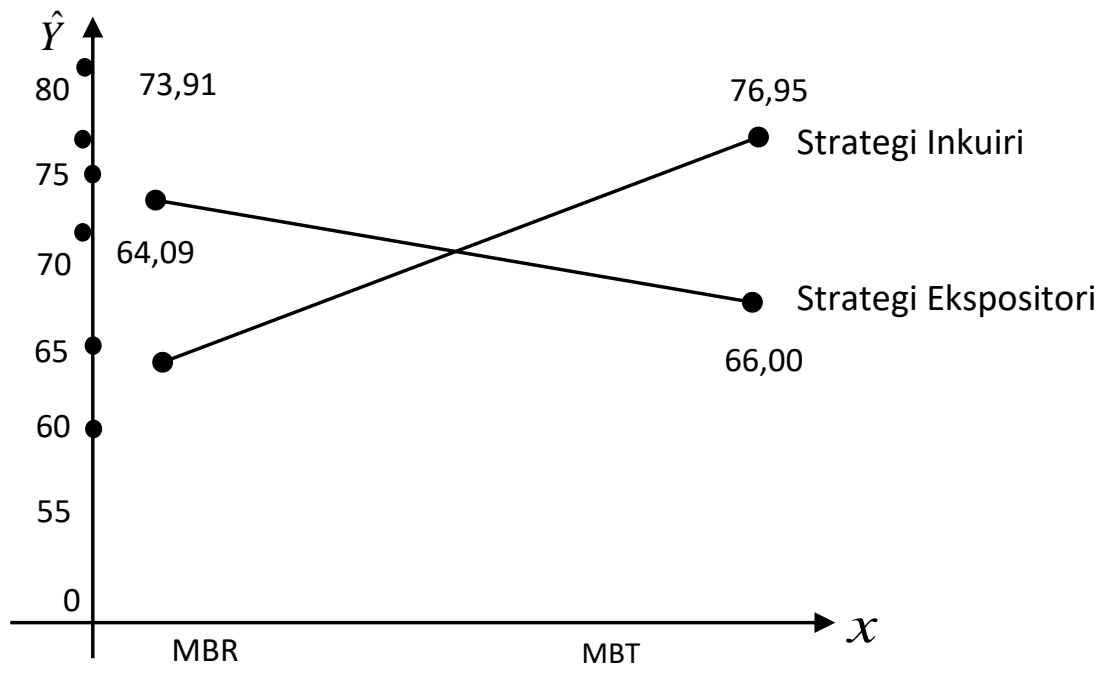

Gambar 1. Grafik Interaksi antara Strategi mengajar dengan Motivasi berpestasi terhadap Hasil Belajar Pelestarian lingkungan hidup

Oleh karena adanya interaksi antara strategi mengajar dan motivasi berpestasi dalam mempengaruhi hasil belajar pelestarian lingkungan hidup serta data yang diperoleh dalam penelitian ini berasal dari sampel yang jumlahnya sama dalam sel ANAVA, maka pelu diadakan uji lanjut dengan menggunakan uji Tuckey.

Tabel 4. Ringkasan Hasil Perhitungan Uji Lanjut dengan Uji-Tuckey

\begin{tabular}{|c|c|c|l|}
\hline $\begin{array}{c}\text { Nilai kelompok yang } \\
\text { dibandingkan }\end{array}$ & \multirow{2}{*}{$F_{\text {hitung }}$} & $\mathrm{F}_{\text {tabel }}$ & \multirow{2}{*}{ Keterangan } \\
\cline { 3 - 3 } & & $\alpha=0,05$ & \\
\hline$\mu_{11}$ dan $\mu_{21}$ & 11,53 & $2,44 \mathrm{Dk}(22: 20)$ & Valid \\
\hline$\mu_{11}$ dan $\mu_{12}$ & 13,54 & $2,44 \mathrm{Dk}(22: 20)$ & Valid \\
\hline$\mu_{11}$ dan $\mu_{22}$ & 3,20 & $2,24 \mathrm{Dk}(22: 22)$ & Valid \\
\hline$\mu_{12}$ dan $\mu_{21}$ & 2,01 & $2,46 \mathrm{Dk}(20: 20)$ & Tidak Valid \\
\hline$\mu_{22}$ dan $\mu_{21}$ & 8,33 & $2,44 \mathrm{Dk}(22: 20)$ & Valid \\
\hline$\mu_{22}$ dan $\mu_{12}$ & 10,33 & $2,44 \mathrm{Dk}(22: 20)$ & Valid \\
\hline
\end{tabular}

\section{Pembahasan}

Hasil Belajar Pelestarian Lingkungan Hidup yang Diajar dengan Strategi Inkuiri Lebih Tinggi dari Hasil Belajar yang Diajar dengan Strategi Ekspositori

Berdasarkan hasil perhitungan dalam penelitian yang diperoleh, terlihat bahwa hasil belajar pelestarian lingkungan hidup pada siswa yang diajar dengan strategi inkuiri adalah lebih tinggi jika dibandingkan dengan hasil belajar pelestarian lingkungan hidup yang diajar dengan strategi ekspositori. Hal ini dimungkinkan karena dalam pembelajaran dengan menggunakan strategi inkuiri, siswa lebih mandiri ketika mengikuti pembelajaran. Strategi pembelajaran inkuiri mengajak siswa lebih aktif, kreatif dan inovatif dalam mengikuti pembelajaran saat proses pembelajaran berlangsung. Untuk lebih mempercepat pemahaman terhadap materi pembelajaran siswa lebih aktif mencari cara-cara bagaimana agar dia lebih cepat memahami materi pembelajaran tersebut, artinya siswa dapat berfikir lebih kreatif untuk menemukan inovasi atau teoti dan cara yang lebih sederhana untuk memamahi materi pembelajaran yang diikuti.

Dalam strategi inkuiri, siswa lebih banyak mengambil keputusan dari pada guru, 
artinya siswa menemukan sendiri jawaban permasalahan pembelajaran. Hal ini sesuai apa yang dikemukakan Sanjaya (2007:193) bahwa strategi inkuiri adalah rangkaian kegiatan pembelajaran yang menekankan pada proses berpikir secara kritis dan analitis untuk mencari dan menemukan sendiri jawaban dari suatu masalah yang dipertanyakan. Artinya bila guru benar-benar menerpkan strategi ini saat proses pembelajaran berlangsung, maka siswa lebih percaya diri dalam menentuka jawan permasalahan materi pembelajaran sehingga dia lebih cepat memahami materi yang diajarkan oleh guru.

Sedangkan dalam proses pembelajaran dengan strategi ekspositori siswa lebih cenderung mengikuti teori-teori yang diberikan oleh guru. Proses pembelajaran berlangsung konvensional, artinya pembelajaran berlangsung dengan cara-cara yang lama, yaitu proses pembelajaran berpusat pada guru. Biasanya siswa sepenuhnya mengikuti teori yang diberikan oleh guru bagaimana cara memahami materi pembelajaran. Hampir tidak ada usaha atau kreativitas siswa dalam menemukan jawaban yang lebih sederhana menurut cara siwa tersebut. Hal ini sesuai dengan apa yang dikemukakan Roy Killen dalam (Sanjaya, 2007:177) strategi ekspositori adalah strategi pembelajaran langsung (direct insructioni). Dalam strategi ini materi pelajaran disampaikan langsung oleh guru. Siswa tidak dituntut untuk menemukan materi itu. Hal ini akan menunjukkan kekakuan bagi siswa dalam mengambil setiap keputusannya. karena siswa kurang kesempatan untuk mengembangkan kemampuan yang dimiliki.

Uraian di atas memberikan gambaran, bahwa strategi inkuiri lebih tepat diberikan kepada siswa ketika memberikan materi pembelajaran pelestaria lingkungan hidup daripada strategi ekspositori. Karena siswa lebih aktif, kreatif dan inovatif menentukan jawabannya dalam menyelesaikan permasalahan pelestarian lingkungan hidup. Hal ini terbukti dari data yang diperoleh menunjukkan bahwa rata-rata hasil belajar pelestarian lingkungan hidup yang diajar dengan strategi inkuiri lebih tinggi daripada hasil belajar pelestarian lingkungan hidup yang diajar dengan strategi ekspositori. Dari hasil perbandingan rata-rata yang diperoleh memberikan simpulan bahwa hasil perbandingan rata-rata hasil belajar pelestarian lingkungan hidup yang diajar dengan strategi inkuiri lebih tinggi dari hasil belajar pelestarian lingkungan hidup yang diajar dengan strategi ekspositori. Hal ini sesuai dengan dugaan sebelumnya yang mengunggulkan strategi inkuiri dalam pembelajaran pelestarian lingkungan hidup. Keunggulan dari strategi inkuiri yang dipaparkan dalam kerangka berpikir terbukti secara empiris di lapangan, sehingga hasil ini telah menguatkan bahwa dengan strategi inkuiri hasil belajar pelestarian lingkungan hidup lebih baik.

\section{Hasil Belajar Pelestarian Lingkungan Hidup Siswa yang Memiliki Motivasi berpestasi Tinggi Lebih Tinggi dari Hasil Belajar Siswa yang Memiliki Motivasi Berpestasi Rendah}

Untuk menyelesaikan suatu masalah setiap siswa berbeda-beda dalam melakukannya. Ada yang suka melakukannya dengan caranya sendiri dan ada pula yang melakukannya dengan cara yang telah diperintahkan oleh guru. Hal ini tergantung kepada sikap yang dimiliki oleh siswa tersebut, artinya bila siswa tersebut memiliki sikap yang positif artinya memiliki motivasi untuk berprestasi, maka siswa tersebut akan melaksanakan aktivitasnya dengan cara sendiri untuk menyelesaikan masalah pembelajaran yang diikuti. Sedangkan bila siswa tersebut kurang memiliki motivasi berprestasi, maka dalam melaksanakan aktivitasnya dia cenderung melakukannya sesuai dengan perintah atau arahan dari guru. Hal ini menjelaskan bahwa dalam mengambil keputusan akan lebih kaku dan kurang terbuka.

Siswa yang memiliki motivasi yang tinggi, dia akan lebih berupaya mencari cara untuk mendapatkan tujuan yang diinginkan. Hal ini sesuai apa yang dikemukakan Sardiman (2004:2) bahwa motivasi adalah sebagai kekuatan, dorongan, kebutuhan, semangat, tekanan, atau mekanisme psikologi yang mendorong seseorang atau sekelompok orang untuk mencapai prestasi tertentu sesuai dengan apa yang dikehendaki". Selanjutnya Usman (2006:223) menjelaskan motivasi ialah keinginan untuk berbuat sesuatu, sedangkan motif adalah kebutuhan (need), keinginan (wish), dorongan (desire) atau impuls. Atinya siwa yang memiliki motivasi untuk berprestasi akan lebih giat dan aktif dalam mengikuti proses pembelajaran.

Hasil yang diperoleh dari penelitian dimana siswa yang memiliki motivasi 
berpestasi tinggi lebih bertanggungjawab, percaya diri, lebih kreatif, menghargai waktu, dan memiliki niat untuk lebih maju lagi. Dia ingin berbeda dengan temannya yang lain dan lebih berfikir positif sehingga selalu berupaya agar lebih baik daripada yang lain.

Sisawa yang memiliki motivasi berpestasi tinggi akan mempengaruhi aktivitasnya mengikuti proses pembelajaran tergantung dari keyakinannya mampu atau tidak untuk melakukannya dan sebaliknya siswa yang memiliki motivasi berpestasi rendah tidak suka melakukan aktivitas untuk menemukan sendiri jawaban tetapi lebih cenderung mengikuti dan bahkan meniru sepenuhnya terhadap teori-teori yang sudah ada sebelumnya.

Keputusan yang diambil oleh siswa yang memiliki motivasi berprestasi yang tinggi sering lebih akurat dan lebih menarik untuk dipelajari daripada siswa yang kurang memiliki motivasi berprestasi. Oleh karena itu hasil belajar yang diperoleh dimana siswa yang memiliki motivasi berpestasi tinggi lebih baik dari hasil belajar siswa yang memiliki motivasi berpestasi rendah. Hasil temuan menunjukkan rata-rata hasil belajar pelestarian lingkungan hidup yang memiliki motivasi berpestasi tinggi lebih tinggi hasilnya bila dibandingkan dengan hasil belajar siswa yang memiliki motivasi berpestasi rendah. Hal ini mendukung apa yang dinyatakan hipotesis penelitian bahwa siswa yang memiliki motivasi berpestasi tinggi hasil belajarnya lebih tinggi dari hasil belajar siswa yang memiliki motivasi berpestasi rendah dalam materi pembelajaran pelestarian lingkungan hidup.

\section{Interaksi Antara Strategi Mengajar dengan Motivasi Berpestasi terhadap Hasil Belajar Pelestarian Lingkungan Hidup}

Dengan demikian hasil pengujian sesuai dengan pengujian hipotesis dan teori bahwa strategi pembelajaran inkuiri mempunyai hasil belajar yang yang lebih tinggi daripada strategi pembelajaran ekspositori. Hal ini diakibatkan karena pada strategi inkuiri kegiatan pembelajaran menekankan pada siswa untuk berpikir secara kritis dan analitis untuk mencari dan menemukan sendiri jawaban dari suatu masalah yang dipertanyaka, sehingga siswa lebih percaya diri dan lebih bebas dalam menyampikan pendapat atau temuannya hal ini akan mengakibatkan proses pembelajaran lebih menarik dan dapat meningkatkan hasil belajar siswa.

Hipotesis kedua juga teruji yaitu bahwa siswa yang memiliki motivasi berpestasi tinggi mempunyai hasil belajar yang yang lebih tinggi daripada siswa yang mempunyai motivasi berpestasi yang rendah. Hal ini diakibatkan karena siswa yang mempunyai motivasi berpestasi tinggi lebih suka menetapkan sendiri tujuan prestasinya, lebih suka menghindari tujuan prestasi yang mudah dan sukar, artinya mereka lebih menyukai tujuan yang sesuai dengan kemampuan mereka, lebih menyukai balikan yang cepat dan efisien mengenai prestasi mereka, dan lebih bertanggung jawab terhadap pemecahan masalah.

Sedangkan hipotesis ke tiga yang menyatakan ada interaksi antara strategi pembelajaran dengan motivasi berprestasi. Dalam penelitian ini ditemukan bahwa siswa yang memiliki motivasi berprestasi yang tinggi memiliki hasil belajar yang lebih baik dari pada siswa yang memiliki motivasi berprestasi rendah bila diberikan strategi pembelajaran inkuiri. Dan ditemukan juga bahwa siswa yang memiliki motivasi berprestasi rendah memiliki hasil belajar yang lebih tinggi dari pada siswa yang memiliki motivasi berprestasi tinggi bila diajar dengan strategi ekspositori. Hal ini diakibatkan oleh siswa yang mempunyai motivasi berprestasi tinggi lebih suka dengan tantangan dan menemukan sendiri atau berupaya sendiri dalam menemukan awabanjawaban permasalahan yang dihadapi seperti tuntutan strategi inkuiri. Sebaliknya siswa yang memiliki motivasi berprestasi rendah cenderung mengikuti aahan-arahan dari pada guru mereka kurang berminat menemukan sendiri jawapannya.

Dengan demikian siswa yang memiliki motivasi berprestasi yang lebih tinggi lebih baik diberikan strategi pembelajaran inkuiri dan sebaliknya siswa yang memiliki motivasi berprestasi rendah lebih baik diberikan strategi ekspositori.

\section{PENUTUP}

1. Hasil belajar pelestarian lingkungan hidup yang diajar dengan strategi inkuiri lebih tinggi dari pada hasil belajar pelestarian lingkungan hidup yang diajar dengan strategi ekspositori. 
2. Hasil belajar pelestarian lingkungan hidup yang memiliki motivasi berprestasi tinggi lebih tinggi dari hasil belajar pelestarian lingkungan hidup yang memiliki motivasi berprestasi rendah rendah.

3. Terdapat interaksi antara strategi mengajar dan motivasi berprestasi terhadap hasil belajar pelestarian lingkungan hidup SMA Negeri 1 Lintong Nihuta dan SMA Negeri 1 Paranginan Kelas XI Kabupaten Humbang Hasundutan. Dalam meningkatkan hasil belajar pelestarian lingkungan hidup, siwa yang memiliki motivasi berprestasi tinggi lebih efektif di ajar dengan menggunakan strategi inkuiri, sedangkan siswa yang mempunyai motivasi berprestasi rendah, lebih efektif diajar dengan menggunakan strategi ekspositori.

\section{DAFTAR PUSTAKA}

Darsono. W.F (1995). Pendidikan ingkungan Hidup, Jakarta:BumiAksara

Dick, W. \& Carey, L. (2005). The systematic Design of Instructional. New York: Longman.

Gagne, R.M. Brigs, L.J. (1979). Principles of Instructional Design, New York: Holt, Rinehart and Winston.

Gibson, (1997) Organisasi: Perilaku, Struktur, dan proses. Terjemahan: Djarkasih. Jakarta: Gelora Aksara Pratama.

Hamalik O. (2004) Proses Belajar Mengajar. Jakarta : Bumi Aksara.

Hamzah. Uno. B. (2006). Teori Motivasi dan Pengukurannya, Analisis di Bidang Pendidikan. Jakarta: Bumi Aksara.

Handoko, T. Hani. (2001). Manajemen Personalia dan Sumber Daya Manusia. Edisi 2, Cetakan 14, Yogyakarta : BPFE Yogyakarta.

Hestiyanto.Yusman (2010). Geografi 2 SMA Kelas XI. Jakarta: Yudistira

Husaini Usman. (2006). Manajemen, Teori, Praktik, dan Riset Pendidikan. Jakarta:Bumi Aksara.

Mathis, Robert L dan John H. Jakcson. (2006). Human Resource Management: Manajemen Sumber Daya Manusia, Buku I, Alih Bahasa: Diana Angelia. Jakarta : Salemba Empat.

Merill, MD. (1981). A Lesson Based on the Componen Display Theory: New Jersey:Lawrence Erlbaum Asc.

Miarso, Y. (2005). Menyemaih Benih Teknologi Pendidikan, Jakarta: Kecana.
Morrison, E. W. (1994). Role Definitions and Organizational Citizenship Behavior: The Importance of The Employee's Perspective. Academy of Management Journal, Vol. 37 (4): 1543-1567.

Robbins. (2006). Perilaku Organisasi. Alih Bahasa Hadiana Pudja Atmaka, Jakarta : Prehalindo.

Romizwoski, A.J. (1981). Instructional Design System, Decision Making in Course Planning and Curriculum Design. London: Kogan

Sabri, Ahmad. (2010). Strategi Belajar Mengajar Micro Teaching. Ciputat. Quantum Teaching.

Sagala, Syaiful. (2007). Manajemen Strategik dalam Peningkatan Mutu Pendidikan. Bandung: Alfabeta.

Sanjaya, Wina. (2007). Strategi Pembelajaran, Jakarta: Kencana Prenada Media Grup

Sardiman, A.M. (2004). Interaksi dan Motivasi Belajar Mengajar. Jakarta: Raja Grafindo Persada

Sopiah. (2008). Perilaku Organisasi. Yogyakarta: Andi.

Sudjana (2001). Metode dan Teknik Pembelajaran Partisipatif, Bandung: Falah Production.

Sudjana. (2005). Metode Statistika, Bandung: Tarsito.

Sutrisno, Edy. (2009). Manajemen Sumber Daya Manusia. Jakarta: Kencana.

Sutrisno, Edy. (2010). Budaya Organisasi. Jakarta: Kencana.

Thoha, Mifta, (2009). Perilaku Organisasi Konsep daasr dan Aplikasinya. Jakarta: CV. Rajawali,

Trianto. (2010) Mendesain Model Pembelajaran inovatif-progresif, Jakarta:Kencana

Usman, H . (2006). Manajemen: Teori, Praktik, dan Riset Pendidikan. Jakarta: Bumi Aksara.

Wahjosumidjo. (2008), Kepemimpinan Kepala Sekolah. Jakarta: Raja Grafindi Persada.

Wardiyatmoko.K. (2006). Geografi untuk SMA Kelas XI, Jajarta: Erlangga. 